\title{
Occurrence, toxicity, production and detection of Fusarium mycotoxin: a review
}

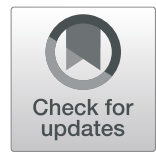

Fang Ji ${ }^{1,2}$, Dan He${ }^{1}$, A. O. Olaniran ${ }^{2}$, M. P. Mokoena ${ }^{2}$, Jianhong $\mathrm{Xu}^{1,3^{*}}$ and Jianrong Shi ${ }^{1,3^{*}}$ (D)

\begin{abstract}
Fusarium mycotoxin contamination of both foods and feeds is an inevitable phenomenon worldwide. Deoxynivalenol, nivalenol, zearalenone, T-2 toxin and fumonisin B1 are the most studied Fusarium mycotoxins. Cocontamination of mycotoxins has also been studied frequently. Fusarium mycotoxins occur frequently in foods at very low concentrations, so there is a need to provide sensitive and reliable methods for their early detection. The present review provides insight on the types, toxicology and occurrence of Fusarium mycotoxins. It further elucidates various detection methods of mycotoxin production from Fusarium strains, with a special focus on chromatographic and immunochemical techniques.
\end{abstract}

Keywords: Fusarium mycotoxins, Toxicology, Occurrence, Detection

\section{Introduction}

Annually, $25-50 \%$ of crops harvested worldwide are contaminated with mycotoxins (Ricciardi et al. 2013). Fusarium head blight (FHB), also known as ear disease or scab, is a worldwide disease of wheat, corn, barley, rice and other small grains. Over the past decades, FHB has become one of the most serious fungal diseases, attributable to climate change and modern agricultural practices, causing tremendous economic losses worldwide (Osborne \& Stein 2007). Fusarium mycotoxins are secondary metabolite produced by Fusarium species during growth and storage. They also have chemical and thermal stability. Furthermore, mycotoxins are passed from the contaminated feed to animals and eventually to humans. Mycotoxins exhibit both acute and chronic toxic effects in humans and animals. The outbreak of the Fusarium toxicity has been reported in many countries, such as Europe, Asia, Africa, New Zealand and South America (Marin et al. 2013). Therefore, to protect human health, some countries have continuously

\footnotetext{
*Correspondence: xujianhongnj@126.com; jianrong63@126.com

'Jiangsu Key Laboratory for Food Quality and Safety-State Key Laboratory Cultivation Base, Ministry of Science and Technology/Key Laboratory for Control Technology and Standard for Agro-product Safety and Quality, Ministry of Agriculture and Rural Affairs/Key Laboratory for Agro-product Safety Risk Evaluation (Nanjing), Ministry of Agriculture and Rural Affairs/ Collaborative Innovation Center for Modern Grain Circulation and Safety/ Institute of Food Safety and Nutrition, Jiangsu Academy of Agricultural Sciences, Nanjing 210014, Jiangsu, China

Full list of author information is available at the end of the article
}

monitored the maximum levels of mycotoxins in foods and other commodities (Table 1) (Ferrigo et al. 2016; Moretti et al. 2017; Selvaraj et al. 2015).

\section{Types and toxicities of Fusarium mycotoxins}

Fusarium species produce three most important classes of mycotoxins namely: trichothecenes, zearalenone (ZEN), and fumonisins (FBs).

\section{Trichothecenes}

Trichothecenes are the most important class of Fusarium mycotoxins, and they are also the most diverse chemical composition. They belong to a large family that contains many chemically related mycotoxins. Fusarium, Myrothecium, and Stachybotrys can produce trichothecenes, although they come from taxonomically different genera. Trichothecenes are one of the potential threats to the health of humans and animals worldwide (Li et al. 2011).

Trichothecenes are extremely prevalent with molecular weights ranging from 200 to $500 \mathrm{Da}$. They include more than 200 toxins, which have a substantial sesquiterpenoid structure, with or without macrocyclic esters or ester ether bridges between C-4 and C- 15 . In addition, trichothecenes consist of 12,13-epoxyalkylene groups that are responsible for cytotoxicity, as well as 9,10 double bonds with different side-chain substitutions (McCormick et al. 2011). Trichothecenes 
Table 1 Allowable limits of Fusarium mycotoxins in food and feeds in certain countries and regions

\begin{tabular}{|c|c|c|c|c|}
\hline Range & Toxin & Country & Applicable Products & Limit $(\mu \mathrm{g} / \mathrm{kg}$ \\
\hline \multirow[t]{44}{*}{ Food } & DON & China & Cereals and their products & 1000 \\
\hline & & EU & Raw durum and oats, wet-milled corn & 1750 \\
\hline & & & Unprocessed cereals other than hard wheat, oats, and corn & 1250 \\
\hline & & & Cereal that can be consumed directly and cornflakes less than or equal to $500 \mu \mathrm{m}$ in size & 750 \\
\hline & & & Bread, snacks, desserts, and breakfast cereals & 500 \\
\hline & & & Cereal-based foods for infants and young children & 200 \\
\hline & & America & Wheat for food milling & 2000 \\
\hline & & & Final products made using edible wheat & 1000 \\
\hline & & Canada & Unpurified soft wheat in China & 2000 \\
\hline & & & Soft wheat flour (adult food) & 1200 \\
\hline & & & Soft wheat flour (baby food) & 600 \\
\hline & & Armenia & Wheat & 700 \\
\hline & & & Barley & 1000 \\
\hline & & Belarus & Wheat & 700 \\
\hline & & & Baby food & Prohibited \\
\hline & & Bulgaria & Grain and products made from grain for direct consumption or as processed food ingredients & 1000 \\
\hline & & & Cereals which will be stored or subjected to further physical processing prior to consumption & 2000 \\
\hline & & & Corn and corn products & 1000 \\
\hline & & Cuba & Imported cereals & 300 \\
\hline & & Cyprus & Grain & 1200 \\
\hline & & Serbia & Raw corn & 1750 \\
\hline & ZEN & China & Wheat and flour & 60 \\
\hline & & & Corn and corn flour (slag and slice) & 60 \\
\hline & & EU & Processed cereals for infants and young children & 20 \\
\hline & & & Bread and breakfast cereals & 50 \\
\hline & & & Grain products that can be eaten directly & 75 \\
\hline & & & Corn, corn snacks, and corn breakfast cereals that can be eaten directly & 100 \\
\hline & & & Corn flakes larger than $500 \mu \mathrm{m}$ in size & 200 \\
\hline & & & Corn flakes less than or equal to $500 \mu \mathrm{m}$ in size & 300 \\
\hline & & & Corn treated via wet grinding & 350 \\
\hline & & & Refined corn oil & 400 \\
\hline & & Armenia & All foods & 1000 \\
\hline & & Austria & Wheat, rye, and hard wheat & 60 \\
\hline & & Belarus & Barley, wheat, and corn & 1000 \\
\hline & & & Baby foods & Prohibited \\
\hline & & Bulgaria & Grain and processed grain products for direct consumption or for use as processed food ingredients & 200 \\
\hline & & & Corn and corn products & 200 \\
\hline & & Chile & All foods & 200 \\
\hline & & Columbia & Sorghum & 1000 \\
\hline & & France & Grain and grain products & 50 \\
\hline & FUMS & EU & Corn-based baby foods & 200 \\
\hline & & & Corn snacks and corn breakfast cereals & 800 \\
\hline & & & Corn, corn snacks, and corn breakfast cereals that can be eaten directly & 1000 \\
\hline & & & Corn flakes larger than $500 \mu \mathrm{m}$ in size & 1400 \\
\hline
\end{tabular}


Table 1 Allowable limits of Fusarium mycotoxins in food and feeds in certain countries and regions (Continued)

\begin{tabular}{|c|c|c|c|c|}
\hline Range & Toxin & Country & Applicable Products & Limit $(\mu \mathrm{g} / \mathrm{kg})$ \\
\hline & & & Corn flakes less than or equal to $500 \mu \mathrm{m}$ in size & 2000 \\
\hline & & & Corn treated via wet grinding & 4000 \\
\hline & & America & Edible corn & 2000 \\
\hline & $\mathrm{FB} 1 \& \mathrm{FB} 2$ & Bulgaria & Corn and corn products & 1000 \\
\hline & FB1 & Cuba & Corn and rice & 1000 \\
\hline & FB1 & France & Grain and grain products & 1000 \\
\hline & $\mathrm{T}-2$ & China & Distiller's dried grain with corn solubles for feed & 100 \\
\hline & & & Formulated feeds for pigs and poultry & 1000 \\
\hline & & Armenia & All foods & 100 \\
\hline & & Belarus & Cereal, flour, and shelled oats & 100 \\
\hline & & & Infant food & Prohibited \\
\hline & & Bulgaria & Grain and grain products for direct consumption and for use as processed food ingredients & 100 \\
\hline \multirow[t]{22}{*}{ Feed } & DON & China & Formulated feeds for pigs, calves, and lactating animals & 1000 \\
\hline & & & Formulated feeds for cattle and poultry & 3000 \\
\hline & & Austria & Pannage & 500 \\
\hline & & & Feed for fattening poultry & 1500 \\
\hline & & & Feeds for breeding poultry and laying fowl & 1000 \\
\hline & & & Feeds for beef cattle & 1000 \\
\hline & & Canada & Feeds for livestock and poultry & 5000 \\
\hline & & & Feeds for pigs, calves, and cows & 1000 \\
\hline & & Cuba & All feedstuffs & 300 \\
\hline & & Cyprus & All feedstuffs except coarse grain & 7000 \\
\hline & & & Complete feeds for pigs & 1000 \\
\hline & & & Complete feeds for poultry and fattening calves & 5000 \\
\hline & & & Complete feeds for other animals & 3000 \\
\hline & & Serbia & Feeds & 8000 \\
\hline & ZEN & China & Feeds and distiller's dried grain with corn solubles & 500 \\
\hline & & Austria & Feeds for breeding swine & 50 \\
\hline & & Canada & Feeds for gilts and sows & 3000 \\
\hline & & Cyprus & Feedstuffs & 2000 \\
\hline & & & Complete feeds for piglets & 1000 \\
\hline & & & Complete feeds for all pigs except piglets & 1500 \\
\hline & $\mathrm{T}-2$ & Canada & Feeds for pigs and poultry & 1000 \\
\hline & HT-2 & Canada & Feeds for livestock and poultry & 100 \\
\hline
\end{tabular}

have been subdivided into four groups (A-D) based on the substitution mode of the core structure of 9ene (EPT) by tricyclic 12,13- epoxidation. Type A toxins include T-2, HT-2, neosolaniol (ENNS), and diacetoxyscirpenol (DAS). Type B toxins include deoxynivalenol (DON) and its 3-acetyl and 15-acetyl derivatives, nivalenol (NIV), together with acetylated precursor of NIV [4-acetylnivalenol, also termed Fusarenon-X (FUX)]. Type $C$ trichothecenes contain a C-7/C-8 epoxide, such as crotocin. Type D trichothecenes include roridin $\mathrm{A}$, verrucarin $\mathrm{A}$, and satratoxin
$\mathrm{H}$ which have an extra loop that can link $\mathrm{C}-4$ and $\mathrm{C}$ 15 (McCormick et al. 2011; Pinton \& Oswald 2014). The structures of the trichothecenes are shown in Fig. 1 and Table 2.

\section{Deoxynivalenol}

In recent years, FHB has once again become a major disease threatening food security, and this has led to renewed interest in trichothecenes, such as deoxynivalenol (DON) (Goswami \& Kistler 2004; Van Egmond et al. 2007). 


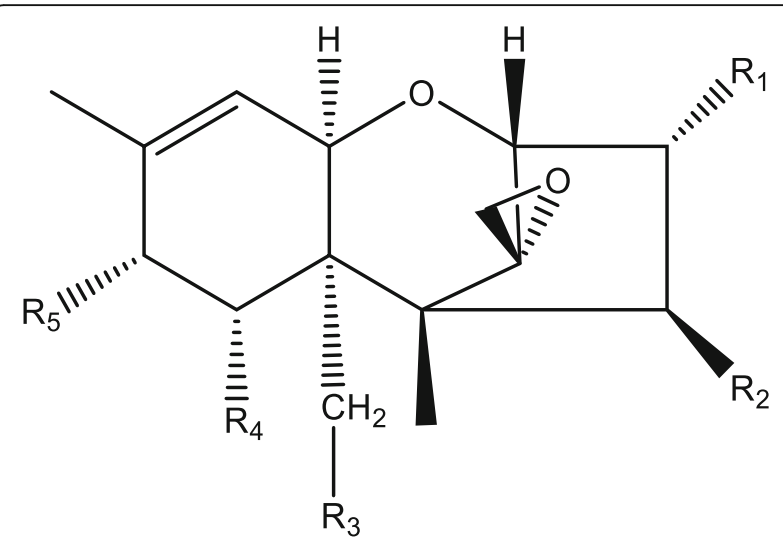

Fig. 1 Structures of trichothecenes (Marin et al., 2013)

DON is mainly produced by Fusarium graminearum and Fusarium culmorum. DON is chemically described as 12,13-epoxy-3 $\alpha, 7 \alpha, 15$-trihydroxytrichothec-9-en-8one $\left(\mathrm{C}_{15} \mathrm{H}_{20} \mathrm{O}_{6}\right)$, crystallizes as colorless needles, stable at extreme temperatures $\left(120-180^{\circ} \mathrm{C}\right)$ and soluble in polar organic solvents such as aqueous acetonitrile, chloroform, methanol, ethanol and ethyl acetate (EFSA 2004a). DON causes vomiting (that is why it is also known as vomitoxin), digestive disorders, oxidative damage, and reproductive toxicities in animals and humans, however, this mycotoxin is not a human carcinogen (Berthiller et al. 2011). The International Agency for Research on Cancer (IARC) classified DON in group 3 (non-carcinogenic substances) (Ostry et al. 2017). DON causes biological barriers and affects cell and organ functions and viability (Maresca 2013). At cellular level, DON binds ribosomal peptide transferase active sites and activates cell kinases to inhibit protein and nucleic acid synthesis (Shifrin \& Anderson 1999; Ueno et al. 1973). Many kinases have been affected, including extracellular signal-regulated kinases, mitogen-activated protein kinases (MAPKs) p38 and c-jun N-terminal kinases (Shifrin \& Anderson 1999). DON triggers MAPKmediated up-regulation of pro-inflammatory cytokine and chemokine expression, and apoptosis (Islam et al. 2006; Shifrin \& Anderson 1999; Zhou et al. 2003). The effects of DON on the immune system are manifold. Due to the different mycotoxin concentrations, timing and duration of exposure, effects can be achieved from immunosuppression to immunostimulation. According to Peraica report, DON is a potent protein synthesis inhibitor that depresses the immune system, and causes dysphagia (Peraica et al. 1999). DON is regarded as a teratogen, neurotoxin, and immunosuppressant agent by The World Health Organization (WHO). In general, DON has been associated with chronic and fatal intoxication of human and animal by eating contaminated food and feed (Rotter et al. 1996).

\section{Nivalenol}

Nivalenol (NIV) was detected from a virulent Fusarium nivale (Fn-2B), isolated from a farmland by Kokoda in 1963 in the Kumamoto region of Japan. Subsequently, Tani and Shigata (1979) found that the organism was lethal to rice, as it produced both NIV and FUX (Tatsuno et al. 1979). NIV (3,4,7,15-tetrahydroxy-12,13-epoxytrichothec-9-en-8-one) is produced mainly by Fusarium graminearum, Fusarium crookwellense, and Fusarium nivale. It co-occurs with FUX and DON in crops such as wheat, barley, and maize. NIV has been recently found in cereal-based products of European countries, and those of Brazil, Japan, Southeast Asia, and China (Turner 2010).

NIV and DON are similar in terms of chemical structure, and also share many toxicological properties such as causing nausea, vomiting, diarrhea, and eventually death. Both toxins inhibit protein synthesis, and increase the levels of stress-activated MAPKs and serum alkaline phosphatase. Gerez et al. (2015) found that the overall liver and kidney weights of female mice were reduced when NIV was added to feeds at up to $700 \mu \mathrm{g} / \mathrm{kg}$ body weight (bw)/day for 2 years. After NIV administration to mice at $12 \mathrm{ppm}$ for up to 8 weeks, the serum IgA concentration increased and IgA became deposited on the

Table 2 Representation of different groups contained in trichothecenes structures

\begin{tabular}{|c|c|c|c|c|c|c|c|c|}
\hline Type & Trichothecene & $\mathrm{R}_{1}$ & $\mathrm{R}_{2}$ & $\mathrm{R}_{3}$ & $\mathrm{R}_{4}$ & $\mathrm{R}_{5}$ & Chemical Formula & Molecular mass (amu) \\
\hline A & Diacetoxyscirpenol & $\mathrm{OH}$ & $\mathrm{OCOCH}_{3}$ & $\mathrm{OCOCH}_{3}$ & $\mathrm{H}$ & $\mathrm{H}$ & $\mathrm{C}_{19} \mathrm{H}_{26} \mathrm{O}_{7}$ & 366 \\
\hline A & Neosolaniol & $\mathrm{OH}$ & $\mathrm{OCOCH}_{3}$ & $\mathrm{OCOCH}_{3}$ & $\mathrm{H}$ & $\mathrm{OH}$ & $\mathrm{C}_{19} \mathrm{H}_{26} \mathrm{O}_{8}$ & 382 \\
\hline A & T-2 Toxin & $\mathrm{OH}$ & $\mathrm{OCOCH}_{3}$ & $\mathrm{OCOCH}_{3}$ & $\mathrm{H}$ & $\mathrm{OCOCH}_{2} \mathrm{CH}\left(\mathrm{CH}_{3}\right)_{2}$ & $\mathrm{C}_{24} \mathrm{H}_{34} \mathrm{O}_{9}$ & 466 \\
\hline A & HT-2 Toxin & $\mathrm{OH}$ & $\mathrm{OH}$ & $\mathrm{OCOCH}_{3}$ & $\mathrm{H}$ & $\mathrm{OCOCH}_{2} \mathrm{CH}\left(\mathrm{CH}_{3}\right)_{2}$ & $\mathrm{C}_{22} \mathrm{H}_{32} \mathrm{O}_{8}$ & 424 \\
\hline B & Deoxynivalenol & $\mathrm{OH}$ & $\mathrm{H}$ & $\mathrm{OH}$ & $\mathrm{OH}$ & $=\mathrm{O}$ & $\mathrm{C}_{15} \mathrm{H}_{20} \mathrm{O}_{6}$ & 296 \\
\hline B & 3-Acetyldeoxynivalenol & $\mathrm{OCOCH}_{3}$ & $\mathrm{H}$ & $\mathrm{OH}$ & $\mathrm{OH}$ & $=0$ & $\mathrm{C}_{17} \mathrm{H}_{22} \mathrm{O}_{7}$ & 338 \\
\hline B & 15-Acetyldeoxynivalenol & $\mathrm{OH}$ & $\mathrm{H}$ & $\mathrm{OCOCH}_{3}$ & $\mathrm{OH}$ & $=0$ & $\mathrm{C}_{17} \mathrm{H}_{22} \mathrm{O}_{7}$ & 338 \\
\hline B & Fusarenon X & $\mathrm{OH}$ & $\mathrm{OCOCH}_{3}$ & $\mathrm{OH}$ & $\mathrm{OH}$ & $=0$ & $\mathrm{C}_{17} \mathrm{H}_{22} \mathrm{O}_{8}$ & 354 \\
\hline B & Nivalenol & $\mathrm{OH}$ & $\mathrm{OH}$ & $\mathrm{OH}$ & $\mathrm{OH}$ & $=0$ & $\mathrm{C}_{15} \mathrm{H}_{20} \mathrm{O}_{7}$ & 312 \\
\hline
\end{tabular}


glomerular mesangium, mirroring human IgA nephropathy (Gerez et al. 2015).

Among various Fusarium mycotoxins tested, NIV exerted one of the highest in vitro immunosuppressive effects on human peripheral blood mononuclear cells. NIV can inhibit the proliferation of human male and female mitogen-stimulated lymphocytes (Nagashima \& Nakagawa 2014). At the mRNA level, NIV and DON modulate Th1type cytokine expression differently at various doses, interacting with lymphocytes to inhibit cell proliferation by stimulating apoptosis (Severino et al. 2006). NIV is more toxic to human promyelocytic leukemia cell line HL60, human lymphoblastic leukemia cell line MLT-4 and rat aortic myoblast cell line A10 than DON (Nagashima \& Nakagawa 2014).

The chronic effects of low oral NIV doses in animal models have been seldom explored, but several countries tolerate only low levels of trichothecenes in cereals (Gouze et al. 2007). China imposes no NIV limit on foods or feeds.

\section{T-2 toxin and HT-2 toxin}

The T-2 toxin [3-hydroxy-4-15-diacetoxy-8ct-(3-methyl butyryloxy) 12,13 epoxytrichothec-9-ene] contains an epoxy trichothecene loop. HT-2, a deacetylated form of T2 , is the principal metabolite of T-2. The toxicities of T-2 and HT-2 are similar, since both contain the epoxy sesquiterpenoid moiety. Consequently, the toxicity of T-2 may be partly attributable to HT-2 for T-2 is rapidly metabolized to HT-2 (Ndossi et al. 2012). Of all Fusarium species, Fusarium langsethiae seems to be the major producer of T-2 and HT-2 followed by Fusarium poae and Fusarium sporotrichioides (Glenn \& Quillin 2007; Thrane et al. 2004). T-2 and HT-2 contaminate many grains, such as maize, oat, barley, wheat, rice, and soybeans.

$\mathrm{T}-2$ is considered one of the most acutely toxic trichothecenes, causing a wide range of toxic effects in animals. Acute T-2 toxicity has been studied in rats, mice, guinea pigs, and pigeons, with the toxin administered intravenously, orally, subcutaneously, intraperitoneally, or intratracheally (Bouaziz et al. 2013). Symptoms of acute poisoning include nausea, vomiting, abdominal pain, diarrhea, bloody stools, cartilage tissue damage, weight loss, decreased immunity, decreased plasma glucose levels, and pathological changes in the liver and stomach. (Li et al. 2011). T-2 at 2, $000 \mu \mathrm{g} / \mathrm{kg}$ reduced lymphocyte numbers and caused hepatopancreatic necrosis in the black tiger shrimp. In addition, T-2 at 2, $500 \mu \mathrm{g} / \mathrm{kg}$ reduced body weight, feed ingestion, feed conversion, and hemoglobin concentration in rainbow trout. $\mathrm{T}-2$ at $1,000 \mu \mathrm{g} / \mathrm{kg}$ dose in catfish reduced intestinal immunity and increased mortality by up to $84 \%$ (Sehata et al. 2004). The main action of T-2 is to inhibit protein synthesis and secondary destruction of DNA and RNA synthesis (Doi et al. 2008).

T-2 can affect cell cycle, and induce chondrocytes, human astrocytes, mouse embryonic stem cells, pig primary hepatocytes, hematopoietic cells in bone marrow and spleen red pulp and epidermal basal cell apoptosis, indicating that T-2 can induce cell death with high proliferation activity (Fang et al. 2012; Shinozuka et al. 1998; Weidner et al. 2013).

In addition, T-2 targets the immune system, alters leukocyte counts, triggers delayed-type hypersensitivity, leads to depletion of certain hematopoietic progenitor cells, reduces antibody formation, and enhances allograft rejection and lectin promotion (Creppy 2002). Pigs and horses are among the animals that are most sensitive to $\mathrm{T}-2$, the major effects of which are immunological and hematological in nature. In quail, T-2 reduced the activity of blood alkaline phosphatase, an enzyme that plays an important role in the innate immune response, increased the levels of glutamic-pyruvic transaminase and glutamic-oxaloacetic transaminase (Madheswaran et al 2004; Nemcsok \& Boross 1982).

\section{Zearalenone}

Zearalenone (ZEN) or called ZEA, previously known as F-2 toxin, is a resorcyclic acid lactone [6-(10-hydroxy-6oxo-trans-1-undecenyl)- $\beta$-resorcyclic acid lactone $\left(\mathrm{C}_{18} \mathrm{H}_{22} \mathrm{O}_{5}, M W: 318.36\right.$, CAS 17924-92-4)]. In mammals, the ketones in C-8 are reduced to two stereoisomeric metabolites (the a- and b-isomers). The structures of ZEN and its derivatives are shown in Fig. 2. Various ZEN metabolites are produced by fungi, but at lower concentrations. The relative concentrations of the individual toxins vary among host plants and geographical regions. These include several Fusarium species (Fusarium graminearum, Fusarium culmorum, Fusarium crookwellense, and Fusarium equiseti) that are known to also produce other toxins including DON, NIV, and FUX (Frizzell et al. 2011). ZEN is a whitish, crystalline toxin with a melting point of $164{ }^{\circ} \mathrm{C}-165^{\circ} \mathrm{C}$. ZEN is fatsoluble, insoluble in water, but soluble in alkalis and various organic solvents. ZEN is thermostable during storage, milling, processing, and cooking (EFSA 2004b). ZEN contaminates corn, barley, oats, wheat, sorghum, millet, rice, flour, malt, soybeans, and beer. ZEN derivatives $[\alpha$-zearalenol $(\alpha$-ZEN), $\beta$-zearalenol $(\beta$-ZEN), $\alpha$ zearalanol $(\alpha-Z A L), \beta$-zearalanol $(\beta-Z A L)$, and zearalanone (ZAN) have been detected in corn stems, rice cultures, corn silage, corn products, and soya meal (Marin et al. 2011). The ZEN limits in corn and other cereals are currently in the range of 50 to $1000 \mu \mathrm{g} / \mathrm{kg}$.

(Table 1). Several in vivo studies found that ZEN principally targeted the reproductive system. In laboratory animals, the toxic effects included changes in 
reproductive tract, uterine enlargement, reduced fertility, increased embryo-lethal resorption, and changes in serum levels of progesterone and estradiol (Koraichi et al. 2012). ZEN and its metabolites $\alpha$-ZEN and $\beta$-ZEN exert estrogenic effects, since they are structurally similar to estrogen; the toxins bind competitively to estrogen receptors, as found in pigs and sheep. In addition, ZEN exhibits relatively low acute toxicity (oral $\mathrm{LD}_{50}$ values > $2000-20,000 \mathrm{mg} / \mathrm{kg} \mathrm{bw}$ ) after oral administration in mice, rats, and guinea pigs (Schoevers et al. 2012). Furthermore, ZEN is immunotoxic, hepatotoxic, hematotoxic, nephrotoxic and enhances lipid peroxidation (Choi et al. 2012). ZEN induces liver lesions and subsequent hepatocarcinoma, and alters hepatic function in rabbits, rats, and gilts (Pistol et al. 2014). Recent studies indicated that ZEN may stimulate the growth of human breast cancer cells that express the estrogen receptors (Ahamed et al. 2001).

\section{Fumonisins}

Fumonisins (FBs) were initially isolated from corn cultures of Fusarium moniliforme in South Africa (Gelderblom et al. 1988). The structures of these mycotoxins as shown in Fig. 3 and Table 3 were first reported by Marasas et al. in 1988 (Scott 2012). Subsequently, fumonisins have been isolated from other Fusarium species, such as Fusarium verticillioides, Fusarium proliferatum and Alternaria alternata f. sp. lycopersici (Bezuidenhout et al. 1988). It is divided into three types: FB1, FB2, and FB3, and are present as natural contaminant in foods and feeds. The molecular structures of fumonisins are shown in Fig. 1 (Soriano 2004). FB1 often contaminates corn and its products, and is the most abundant and most toxic FB. FB1 is a diester of propane-1,2,3-tricarboxylic acid and 2S-amino-12S,16R-dimethyl-3S,5R,10R, 14S,15R-pentahydroxyeicosane, where the C-14 and C-
15 hydroxy groups are esterified with the terminal carboxy group of propane-1,2,3-tricarboxylic acid (TCA). FB2 is a 10-deoxy FB1 while FB3 is a 5-deoxy FB1 (Soriano et al. 2005). The structures of the principal fumonisins are shown in Fig. 3. The symptoms induced by FBs are very broad, including neural tube defects in newborns, brain lesions in horses, pulmonary edema in pigs and cancer in experimental animals. Although FBs have no mutagenicity, they promote cancer development (Summerell \& Leslie 2011). FBs are associated with human apoptosis, esophageal cancer and neural tube defects (Ahangarkani et al. 2014; Scott 2012). FBs can affect the progress of liver cancer in rats, cause bleeding in rabbit brains and have nephrotoxicity to other animals. In addition, FBs are also toxic to pigs, chickens and other farm animals (Ahangarkani et al. 2014). FB1 interferes with myelin synthesis, causes leukoencephalomalacia and liver necrosis in horses, leading to death. Pig intake of FB1 contaminated feed will cause pulmonary edema (Scott 2012). In rodent studies, liver and kidney are the main FB1 targets.

The mechanism by which fumonisin exerts toxic effects is complex. Structurally, fumonisins are similar to sphingoid base (a sphingolipid). They can inhibit the synthesis of ceramide synthase and block the biosynthesis of complex sphingolipids, thereby promoting the accumulation of sphingosine and sphinganine 1phosphate (Wan et al. 2013). As sphingolipids play key roles in cellular regulation, dysfunctional sphingolipid metabolism may account for the observed toxicity. These lipids play an important role at the cellular level. They can maintain cell morphology, promote cell differentiation, regulate growth factor levels, and affect cell carcinogenicity and apoptosis. In addition, they also play a role in maintaining cell membrane structure, enhancing cell interaction and extracellular interaction.

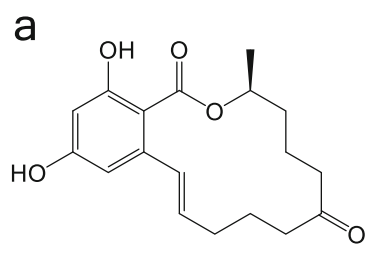

$$
\text { b }
$$
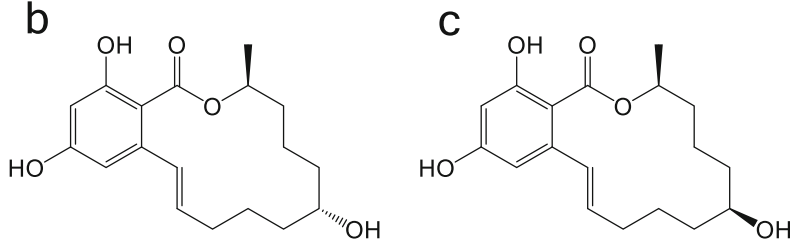

d

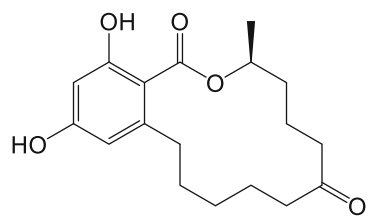

e

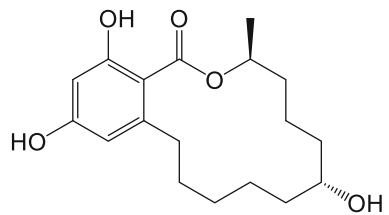

f

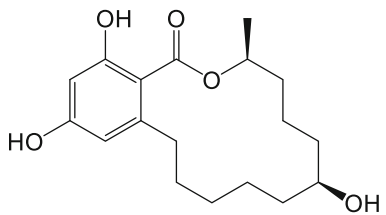

Fig. 2 Chemical structures of ZEN and its derivatives: (a) zearalenone, (b) a-zearalenol, (c) $\beta$-zearalenol, (d) zearalanone, (e) a-zearalanol, and (f) $\beta$ zearalanol (Marin et al., 2013) 


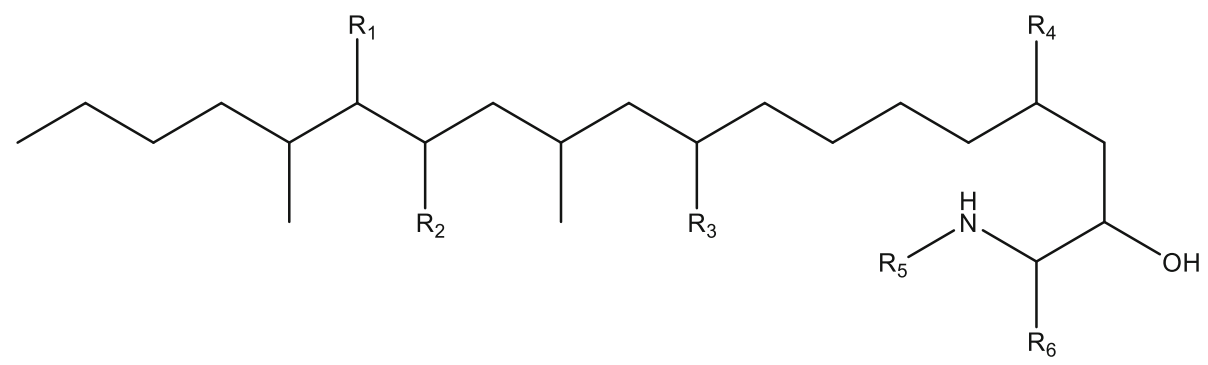

Fig. 3 Structures of the principal fumonisins in foods (FBs: fumonisins of group B) (Marin et al., 2013)

Moreover, sphingolipids also act as secondary messengers in various signal transduction pathways (Ahangarkani et al. 2014).

\section{Occurrence of Fusarium mycotoxins in China}

As early as the 1940s, there are some records about swine toxicosis fed with FHB contaminated wheat in China (Li, 1959). Wheat FHB has seriously occurred for many years in China with most recent epidemic of 2003, 2010, 2012, 2015, 2016 and 2018. As the staple food, wheat plays an important role to feed billions of people in China. The potential hazards of Fusarium mycotoxin contaminated cereals is a threat for human and animal.

Temperature and rainfall are the key climatic factors that affect plants and their associated pathogens as well as mycotoxin concentrations in infected plants. In the middle-to-low valleys of the Huaihe and Yangtze Rivers, the most developed agro-production regions of China, the (typical) humid warm climate encourages FHB epidemics. In 2010, rainfall promotes wheat flowering, leading to the development of $\mathrm{FHB}$, found as the common disease of wheat in Southern China. The total amount of wheat produced in 2010 in Jiangsu and An-hui was 100.81 and 120.65 million $\mathrm{kg}$, respectively.

Li et al. (2014) sampled 76 cereals and oil products of the Yangtze Delta of China, and found that ZEN is the most prevalent toxin, with an incidence of $27.6 \%(9.2 \%$ higher than the legal limit). DON was detected in $7.9 \%$ of the samples (Rui Li et al. 2014). Han et al. reported the levels of DON, 3-ADON, and 15-ADON in wheat and maize samples from Shanghai, China. From 2009 to 2012, $58 \%$ of all maize samples and $80 \%$ of all wheat samples were contaminated by DON. In 2011 to 2012, all 50 wheat and maize samples evaluated were contaminated with low levels of 3-ADON and 15ADON (Han et al. 2014). The authors collected 180 samples in Jiangsu Province from 2010 to 2012. The percentage of DON-positive samples was $74.4 \%$, and that of ZEN-positive samples was $12.8 \%$. The highest DON concentration was $41,157 \mu \mathrm{g} / \mathrm{kg}$, far above the allowable limits (Ji et al. 2014). Li, BT, Liu, and Dong (2015) reported that $39.7 \%$ of maize samples were contaminated by FB1 and FB2 in Southwest China (Renjie Li., 2015). Recent studies have found that $30-80 \%$ corn grains have FB1 and FB2 in the corn grains planted in some provinces in China, and the mean mycotoxin concentration range is from 11 to $13,110 \mu \mathrm{g} / \mathrm{kg}$ (Feng et al. 2011; Wei et al. 2013). Several authors have investigated mycotoxin levels in various cereals and feeds. Table 4 summarizes data obtained over the past 28 years on Fusarium mycotoxin contamination of foods and feeds in China.

\section{Production of Fusarium mycotoxins}

The Fusarium fujikuroi species complexes (FFSC) and Fusarium graminearum species complexes (FGSC) are the major mycotoxin producers, respectively (O'Donnell et al. 2000). The FFSC produces fumonisins. Fusarium verticillioides is the main contaminant of corn, while Fusarium proliferatum is a polyphagous species that was found in many different crops.

Qiu et al. (2014) isolated Fusarium species from maize kernels from Jiangsu and Anhui Provinces, China. They also found that Fusarium verticillioides was the most prevalent species, followed by Fusarium proliferatum, and finally Fusarium graminearum. FUM1 is a gene that plays a key role in fumonisin biosynthesis. They also reported that most Fusarium verticillioides strains have been detected to presence FUM1 (Qiu \& Shi 2014).

Table 3 Representation of different groups contained in fumonisins structures

\begin{tabular}{lllllll}
\hline & $\mathrm{R}_{1}$ & $\mathrm{R}_{2}$ & $\mathrm{R}_{3}$ & $\mathrm{R}_{4}$ & $\mathrm{R}_{5}$ & $\mathrm{R}_{6}$ \\
\hline FB1 & TCA & TCA & $\mathrm{OH}$ & $\mathrm{OH}$ & $\mathrm{H}$ \\
FB2 & TCA & $\mathrm{H}$ & $\mathrm{OH}$ & $\mathrm{H}$ & $\mathrm{CH}_{3}$ \\
FB3 & TCA & TCA & $\mathrm{OH}$ & $\mathrm{H}$ & $\mathrm{CH}_{3}$ \\
FB4 & TCA & TCA & $\mathrm{H}$ & $\mathrm{H}$ & $\mathrm{H}$ \\
\hline
\end{tabular}


The FGSC contains 16 phylogenetically distinct species at least, which can cause FHB in a variety of crops and produce trichothecenes (O'Donnell et al. 2004). In North America and Europe, Fusarium graminearum is predominated in a survey of Fusarium species composition and population structure (Starkey et al. 2007). The distribution of Fusarium asiaticum and Fusarium graminearum is different in location, they are the main etiological agents of FHB in Japan and Korea (Gale et al. 2002; Lee et al. 2012; Suga et al. 2008). In China, both Fusarium graminearum and Fusarium asiaticum are widespread. In the colder northern regions of China, $\mathrm{Fu}$ sarium graminearum isolates are the predominated. In the warm wheat growing areas, Fusarium asiaticum is found principally (Wang et al. 2008). Fusarium species differ in their responses to temperature and moisture, which perhaps influence their distributions in causing infections (Parikka et al. 2012). FGSC strains are usually classified into three trichothecene profiles according to the difference in the production of mycotoxins: (i) DON and 3-acetyldeoxynivalenol (3-ADON chemotype); (ii) DON and 15-acetyldeoxynivalenol (15-ADON chemotype), or (iii) NIV, its acetylated derivatives (NIV chemotype) (Ward et al. 2002). The analysis of the distribution of FGSC and trichothecene chemotypes in cereal crops will help to correctly understand the relationship between disease and mycotoxin pollution, so as to develop effective management strategies for controlling disease and mycotoxin pollution.

\section{Detection of Fusarium mycotoxins}

Mycotoxins can be detected by various techniques, which are broadly divided into instrumental and bioanalytical methods. However, each approach has merits and drawbacks; the method of choice depends on the detection requirements.

\section{Chromatographic methods}

There are many kinds of instrumental detection methods for mycotoxins. Thin layer chromatography (TLC) is a qualitative or semi quantitative method with the longest history in the detection of mycotoxins. High-performance liquid chromatography (HPLC) can couple with different detectors. These detectors include ultraviolet (UV) detection, diode array detection, fluorescence detection or mass spectrometric detection. Gas chromatography can couple with electron capture detection, flame ionization detection (FID), or mass spectrometry (MS) detection (Lippolis et al. 2008; Visconti \& De Girolamo 2005). These methods afford high accuracy and precision, and are used for both quantitative and qualitative analyses. However, they are expensive, require skilled personnel and longer periods for sophisticated sample preparation (Elliott 2011). Thus, instrumental methods are not suitable for normal laboratories or field environments. Chromatographic techniques involving UV and FID are principally employed in confirmatory contexts, thus facilitating compliance with regulations. Occasionally, such techniques serve as reference methods for validation of immunochemical tests.

MS has indisputable advantages of high sensitivity, high selectivity, high throughput and accuracy, making multiresidue analysis possible. Quick, easy, cheap, effective, rugged, and safe (QuEChERS) approaches for sample preparation allow analysis of a wide range of matrices and analytes, and further allowing the simultaneous extraction of the amount of mycotoxins. However, QuEChERS approaches reduce analytical sensitivity, and require preconcentration steps. Alternatively, isotope dilution quantification can improve sensitivity in the absence of preconcentration (Anfossi et al. 2016).

High resolution MS (HRMS) and tandem MS/MS allow (possibly) identification of unknown compounds by analyzing structural information of the compounds. The use of non-selective extraction protocols followed by mass screening employing HRMS or MS/MS has allowed identification of new masked mycotoxins and new members of known groups. The rapid multi-residue LC-MS/MS methods have been used to evaluate mycotoxins level in food and feed.

\section{Immunochemical methods}

Immunoassays based on antibody-antigen reactions are very useful for routine analyses, as these techniques are simple and have been used for rapid mycotoxin detection (Zherdev 2014). Recently, several immunological techniques have been developed, including enzymelinked immunosorbent assays, time-resolved immunochromatographic assays, enzyme-linked aptamer assays, chemiluminescence immunoassays, fluorescence immunoassays, fluorescence resonance energy transfer immunoassays, and metal-enhanced fluorescence assays (Chauhan et al. 2016). Aptamer is an important parameter in these detection techniques. It can bind a variety of peptides, proteins, amino acids, and organic or inorganic molecules, all of which have high affinity and specificity (Torres-Chavolla \& Alocilja 2009). Jodra et al. (2015) developed an electrochemical magnetoimmunosensor to detect FB1 and FB2. The sensor was made of magnetic beads and disposable carbon screenprinted electrodes. Liu et al. (2014) constructed an ultrasensitive immunosensor based on mesoporous carbon and trimetallic nanorattles with special $\mathrm{Au}$ cores. The lower detection limit of ZEN was $1.7 \mathrm{pg} / \mathrm{mL}$, and the assay was found to exhibit good stability and reproducibility.

Because of the strong selectivity of molecular recognition mechanisms, it is difficult to simultaneously assay different compounds or discover new toxins. Osward 
Table 4 Contamination of Fusarium mycotoxins in foods and feeds in China

\begin{tabular}{|c|c|c|c|c|c|}
\hline Product & Number & toxin & $\begin{array}{l}\text { positive samples } \\
(\%)\end{array}$ & Province & Reference \\
\hline \multirow[t]{24}{*}{ Corn } & \multirow[t]{10}{*}{120} & DON & 74.2 & \multirow[t]{10}{*}{ Shanxi } & \multirow[t]{10}{*}{ Wei et al., 2017} \\
\hline & & 3-A-DON & 16.7 & & \\
\hline & & $\begin{array}{l}15-\mathrm{A}- \\
\text { DON }\end{array}$ & 74.2 & & \\
\hline & & NIV & 27.5 & & \\
\hline & & ZEN & 49.2 & & \\
\hline & & FB1 & 74.2 & & \\
\hline & & FB2 & 82.5 & & \\
\hline & & FB3 & 70.0 & & \\
\hline & & $T-2$ & 5.0 & & \\
\hline & & HT-2 & 17.5 & & \\
\hline & \multirow[t]{4}{*}{215} & DON & 84.65 & \multirow[t]{4}{*}{ Twelve provinces } & \multirow[t]{4}{*}{ Ma et al., 2011} \\
\hline & & ZEN & 69.30 & & \\
\hline & & $\mathrm{T}-2$ & 46.05 & & \\
\hline & & HT-2 & 16.28 & & \\
\hline & \multirow[t]{2}{*}{42} & DON & 47.6 & \multirow[t]{2}{*}{ Anhui and Henan } & \multirow{2}{*}{$\begin{array}{l}\text { Xiong et al., } \\
2009\end{array}$} \\
\hline & & ZEN & 78.6 & & \\
\hline & 111 & DON & 16.2 & Anhui & Lu et al., 1994 \\
\hline & 105 & DON & 61.9 & Hebei & Liu et al., 1993 \\
\hline & 284 & DON & 66.6 & Six provinces: Henan, Hubei, Sichuan, Jilin, Guangxi, and Guangdong & $\begin{array}{l}\text { Wang et al., } \\
2007\end{array}$ \\
\hline & \multirow[t]{2}{*}{204} & DON & 50.5 & \multirow[t]{2}{*}{ Seven provinces: Henan, Hebei, Guangxi, Anhui, Sichuan, Ghongqing, and Jiangsu } & \multirow[t]{2}{*}{ Li et al., 2011} \\
\hline & & ZEA & 41.7 & & \\
\hline & 50 & FBs & 26 & Shangdong & Yan et al., 1999 \\
\hline & 70 & FBs & 44.3 & Jilin & Sun et al., 2003 \\
\hline & 50 & FBs & 38.00 & Hubei & Lv et al., 2005 \\
\hline \multirow[t]{20}{*}{ Wheat } & 100 & NIV & 35 & Shanghai & Li et al., 1997 \\
\hline & 100 & DON & 53.0 & & \\
\hline & \multirow[t]{2}{*}{41} & DON & 97.6 & \multirow[t]{2}{*}{ Anhui and Henan } & \multirow{2}{*}{$\begin{array}{l}\text { Xiong et al., } \\
2009\end{array}$} \\
\hline & & ZEN & 68.3 & & \\
\hline & 439 & ZEN & 31.9 & \multirow[t]{2}{*}{ National } & \multirow[t]{2}{*}{ Luo et al., 1989} \\
\hline & 815 & DON & 49.2 & & \\
\hline & 329 & DON & 69.3 & Anhui & Lu et al., 1994 \\
\hline & \multirow[t]{3}{*}{200} & ZEN & 61.0 & \multirow[t]{3}{*}{ Twenty-six provinces } & \multirow{3}{*}{$\begin{array}{l}\text { Cheng et al., } \\
2014\end{array}$} \\
\hline & & DON & 89.0 & & \\
\hline & & $\mathrm{T}-2$ & 42.0 & & \\
\hline & 190 & DON & 66.3 & Six provinces: Henan, Hubei, Sichuan, Jilin, Guangxi, and Guangdong & $\begin{array}{l}\text { Wang et al., } \\
2007\end{array}$ \\
\hline & \multirow[t]{2}{*}{162} & DON & 88.8 & \multirow[t]{2}{*}{ Seven provinces: Henan, Hebei, Guangxi, Anhui, Sichuan, Ghongqing, and Jiangsu } & Li et al., 2011 \\
\hline & & ZEN & 22.9 & & \\
\hline & 183 & DON & 37.99 & National & Wu et al., 2009 \\
\hline & & FBs & 87.34 & & \\
\hline & & $\mathrm{T}-2$ & 97.38 & & \\
\hline & & ZEN & 16.02 & & \\
\hline & 56 & DON & 89.3 & Anhui and Jiangsu & Cui et al., 2013 \\
\hline & 50 & DON & 30 & Ten regions of China, including Shandong, Hebei, Jilin, et al. & $\begin{array}{l}\text { Wang. et al., } \\
2014\end{array}$ \\
\hline & 50 & FBs & 94 & Shangdong & Yan et al., 1999 \\
\hline
\end{tabular}


Table 4 Contamination of Fusarium mycotoxins in foods and feeds in China (Continued)

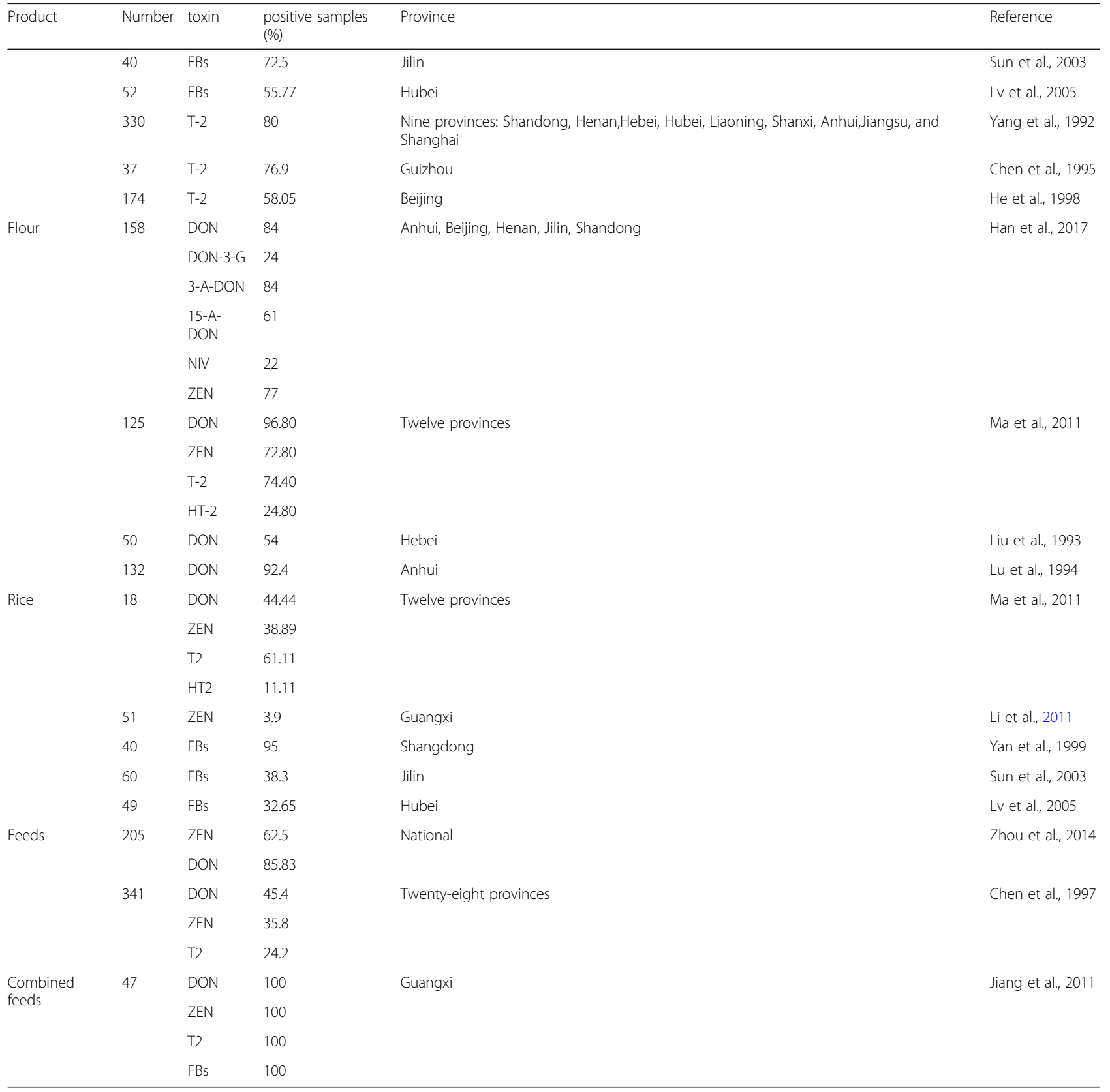

et al. (2013) designed an analytical array that can detect several targets separately in spatially distinct regions. Song et al. (2014) developed an immuno-chromatographic strip test device that simultaneously detect at least 10 different toxins (AFs, DON and analogs thereof, and ZON and analogs thereof). Wang et al. (2013) reported that they developed a unique spectral addresses which can simultaneous detection of many mycotoxins in peanuts. Those mycotoxins include AFB1, DON, ZON, and T-2.

In comparison to chromatographic methods, immunochemical methods afford greater selectivity in terms of monitoring mycotoxin levels which is very important to ensure food safety in developing countries. In addition, due to global changes in climate and the environment, the level of contamination by fungi and their mycotoxins will increase in the future. Risk management requires routine application of efficient control programs such as optimally employing immunoassays.

\section{Conclusion}

In conclusion, the study of Fusarium mycotoxins has attracted increasing attention. Many studies have addressed the toxicokinetic profile, mycotoxin persistence 
and accumulation. The progress of mycotoxin analysis highlights the limitations currently being understood due to their effective impact on animal and human health in food. Co-contamination by several toxic compounds and identification of new compounds in the mycotoxin family both require new toxicological studies to assess. In addition, food from crops is susceptible to fungal contamination, and it has been clearly demonstrated that animals fed the contaminated feed can transmit mycotoxins. Some regulations, especially those established by the European Union, have gradually recognized the risk of contamination by mycotoxins in the food chain. Mycotoxin levels should be monitored routinely and continuously, as the annual levels may vary depending on environmental moisture, climate, temperature changes, plant disease status, and insect pest numbers. Effective management of food safety risks is required, especially including the use of rapid and sensitive immunological techniques.

\section{Abbreviation \\ CSPE: Carbon screen printed electrode; DAD: Diodearray; DAS: Diacetoxyscirpenol; DON: Deoxynivalenol; ECD: Electron capture; ENNS: Neosolaniol; EPT: 12, 13 epoxytrichothec-9-ene; ERK: Extracellular-signal regulated kinase; FBs: Fumonisins; FD: Fluorescence; FFSC: Fusarium fujikuroi species complex; FGSC: Fusarium graminearum species complex; FHB: Fusarium Head Blight; FID: Flame ionization; FRET: Fluorescence resonance energy transfer; FUX: Fusareno-X; GC: Gas chromatography; HPLC: High-performance liquid chromatography; HRMS: High- resolution MS; IARC: Agency for Research on Cancer; JNK: Jun N-terminal kinase; MAPKs: Mitogen-activated protein kinase; MC: Mesoporous carbon; MS: Mass spectrometry; NIV: Nivalenol; QuEChERS: Quick, easy, cheap, effective, rugged, and safe; TLC: Thin-layer chromatography; UV: Ultraviolet; ZAN: zearalanone; ZEN: Zearalenone; a-ZAL: a-zearalanol; $a-Z E N$ : a-zearalenol; $\beta$-ZAL: $\beta$-zearalanol; $\beta$ - ZEN: $\beta$-zearalenol}

\section{Acknowledgements}

The authors acknowledge University of Kwazulu-Natal for valuable support during implementation of the study.

\section{Authors' contributions}

JS, JX and FJ conceived and designed the paper; FJ collected, analyzed literatures and wrote the paper; $\mathrm{DH}$ edited the table and figure; $\mathrm{AOO}$ and MPM reviewed and edited the manuscript. All authors read and approved the manuscript. All authors read and approved the final manuscript.

\section{Funding}

This work was financially supported by the National Natural Science Foundation of China (31471662), the National Agri-food Risk Assessment Project of China (GJFP201700102), Jiangsu Agriculture Science and Technology Innovation Fund (CX (17)1003); Jiangsu Agriculture Science and Technology Innovation Fund (CX (16)1059)

\section{Availability of data and materials \\ Not applicable.}

\section{Competing interests}

The authors declare that they have no competing interests.

\section{Author details}

${ }^{1}$ Jiangsu Key Laboratory for Food Quality and Safety-State Key Laboratory Cultivation Base, Ministry of Science and Technology/Key Laboratory for Control Technology and Standard for Agro-product Safety and Quality, Ministry of Agriculture and Rural Affairs/Key Laboratory for Agro-product Safety Risk Evaluation (Nanjing), Ministry of Agriculture and Rural Affairs/ Collaborative Innovation Center for Modern Grain Circulation and Safety/ Institute of Food Safety and Nutrition, Jiangsu Academy of Agricultural Sciences, Nanjing 210014, Jiangsu, China. ${ }^{2}$ Discipline of Microbiology, School of Life Science, College of Agriculture, Engineering and Science, University of KwaZulu-Natal, Private Bag X54001, Durban 4000, South Africa. ${ }^{3}$ School of Food and Biological Engineering, Jiangsu University, Zhenjiang, Jiangsu, China.

Received: 12 July 2019 Accepted: 10 September 2019

Published online: 29 October 2019

\section{References}

Ahamed, S., Foster, J. S., Bukovsky, A., \& Wimalasena, J. (2001). Signal transduction through the Ras/Erk pathway is essential for the mycoestrogen zearalenoneinduced cell-cycle progression in MCF-7 cells. Molecular Carcinogenesis, 30, 88-98.

Ahangarkani, F., Rouhi, S., \& Azizi, I. G. (2014). A review on incidence and toxicity of fumonisins. Toxin Reviews, 33, 6.

Anfossi, L., Giovannoli, C., \& Baggiani, C. (2016). Mycotoxin detection. Current Opinion in Biotechnology, 37, 120-126.

Berthiller, F., Krska, R., Domig, K. J., Kneifel, W., Juge, N., Schuhmacher, R., \& Adam, G. (2011). Hydrolytic fate of deoxynivalenol-3-glucoside during digestion. Toxicology letters, 206, 264-267.

Bezuidenhout, S. C., Gorst-Allman, C. P., Horak, R. M., Marasas, W. F. O., Spiteller, G. et al. (1988). Structure elucidation of the fumonisins, mycotoxins from Fusarium moniliforme. Chemical Communications, 19, 3.

Bouaziz, C., Bouslimi, A., Kadri, R., Zaied, C., Bacha, H., \& Abid-Essefi, S. (2013). The in vitro effects of zearalenone and T-2 toxins on Vero cells. Experimental and Toxicologic Pathology, 65, 497-501.

Chauhan, R., Singh, J., Sachdev, T., Basu, T., \& Malhotra, B. D. (2016). Recent advances in mycotoxins detection. Biosensors \& Bioelectronics, 81, 532-545.

Chen, Y., Chen, Q., Han, M., Zhou, J., Gong, L., Niu, Y., Zhang, Y., He, L., \& Zhang, L. (2016). Development and optimization of a multiplex lateral flow immunoassay for the simultaneous determination of three mycotoxins in corn, rice and peanut. Food Chemistry, 213, 478-484.

Choi, B. K., Cho, J. H., Jeong, S. H., Shin, H. S., Son, S. W., Yeo, Y. K., \& Kang, H. G. (2012). Zearalenone affects immune-related parameters in lymphoid organs and serum of rats vaccinated with porcine parvovirus vaccine. Toxicological Research, 28, 279-288.

Creppy, E. E. (2002). Update of survey, regulation and toxic effects of mycotoxins in Europe. Toxicology Letters, 127, 19-28.

Doi, K., Ishigami, N., \& Sehata, S. (2008). T-2 toxin-induced toxicity in pregnant mice and rats. International Journal of Molecular Sciences, 9, 2146-2158.

EFSA. (2004a). Opinion of the scientific panel on contaminants in the food chain on a request from the commission related to deoxynivalenol (DON) as undesirable substance in animal feed (Vol. 73, p. 41). EFSA Journal.

EFSA. (2004b). Opinion of the scientific panel on contaminants in the food chain on a request from the commission related to zearalenone as undesirable substance in animal feed (Vol. 89, p. 35). EFSA Journal.

EFSA. (2011). Scientific opinion on the risks for animal and public health related to the presence of T-2 and HT-2 toxin in food and feed (Vol. 9, p. 1). EFSA Journal.

Elliott, T. (2011). Current methods of analysis for the determination of trichothecene mycotoxins in food. TrAC Trends in Analytical Chemistry, 30, 12-19.

Escriva, L., Font, G., \& Manyes, L. (2015). In vivo toxicity studies of fusarium mycotoxins in the last decade: A review. Food and Chemical Toxicology, 78, 185-206.

Fallah, B., Zaini, F., Daei Ghazvini, R., Kachuei, R., Kordbacheh, P., Safara, M., \& Mahmoudi, S. (2016). (2016). The antagonistic effects of Candida parapsilosis on the growth of Fusarium species and fumonisin production. Current Medical Mycology, 2, 1-6.

Fang, H., Wu, Y., Guo, J., Rong, J., Ma, L., Zhao, Z., Zuo, D., \& Peng, S. (2012). T-2 toxin induces apoptosis in differentiated murine embryonic stem cells through reactive oxygen species-mediated mitochondrial pathway. Apoptosis: An international Journal on Programmed Cell Death, $17,895-907$

Feng, Y. Z., Lu, X. H., Tao, B., Pang, M. H., Liu, Y. C., \& Dong, J. G. (2011). Natural occurrence of fumonisins $\mathrm{b} 1$ and $\mathrm{b} 2$ in corn from three main production provinces in China. Journal of Food Protection, 74, 5.

Ferrigo, D., Raiola, A., \& Causin, R. (2016). Fusarium toxins in cereals: Occurrence, legislation, factors promoting the appearance and their management. Molecules, $21,24-29$.

Frizzell, C., Ndossi, D., Verhaegen, S., Dahl, E., Eriksen, G., Sorlie, M., Ropstad, E., Muller, M., Elliott, C. T., \& Connolly, L. (2011). Endocrine disrupting effects of zearalenone, alpha- and beta-zearalenol at the level of nuclear receptor binding and steroidogenesis. Toxicology Letters, 206, 210-217. 
Gale, L. R., Chen, L. F., Hernick, C. A., Takamura, K., \& Kistler, H. C. (2002). Population analysis of Fusarium graminearum from wheat fields in eastern China. Phytopathology, 92, 1315-1322.

GB/T. (2011). China N.C.o. Maximum levels of mycotoxins in foods.

Gelderblom, W. C., Thiel, P. G., \& van der Merwe, K. J. (1988). The chemical and enzymatic interaction of glutathione with the fungal metabolite, fusarin C. Mutation Research, 199, 207-214.

Gerez, J. R., Pinton, P., Callu, P., Grosjean, F., Oswald, I. P., \& Bracarense, A. P. (2015). Deoxynivalenol alone or in combination with nivalenol and zearalenone induce systemic histological changes in pigs. Experimental and toxicologic pathology: Official Journal of the Gesellschaft fur Toxikologische Pathologie., 67, 89-98.

Gilbert, J. T. (2000). Review: Recent developments in research on fusarium head blight of wheat in Canada. Canadian Journal of Plant Pathology, 22, 8-15.

Glenn, L. L., \& Quillin, S. I. (2007). Opposing effects of maternal and paternal socioeconomic status on neonatal feeding method, place of sleep, and maternal sleep time. The Journal of Perinatal \& Neonatal Nursing, 21, 165-172.

Goswami, R. S., \& Kistler, H. C. (2004). Heading for disaster: Fusarium graminearum on cereal crops. Molecular Plant Pathology, 5, 515-525.

Gouze, M. E., Laffitte, J., Pinton, P., Dedieux, G., Galinier, A., Thouvenot, J. P., Loiseau, N., Oswald, I. P., \& Galtier, P. (2007). Effect of subacute oral doses of nivalenol on immune and metabolic defence systems in mice. Veterinary Research, 38, 635-646.

Han, Z., Nie, D., Ediage, E. N., Yang, X., Wang, J., Chen, B., Li, S., On, S. L., De Saeger, S., \& Wu, A. (2014). Cumulative health risk assessment of co-occurring mycotoxins of deoxynivalenol and its acetyl derivatives in wheat and maize: Case study, Shanghai, China. Food and chemical toxicology: An international Journal Published for the British Industrial Biological Research Association, 74, 334-342.

Islam, Z., Gray, J. S., \& Pestka, J. J. (2006). p38 mitogen-activated protein kinase mediates IL-8 induction by the ribotoxin deoxynivalenol in human monocytes. Toxicology and Applied Pharmacology, 213, 235-244.

Ji, F., Xu, J. H., Liu, X., Yin, X. C., \& Shi, J. R. (2014). Natural occurrence of deoxynivalenol and zearalenone in wheat from Jiangsu province, China. Food Chemistry, 157, 393-397.

Koraichi, F., Videmann, B., Mazallon, M., Benahmed, M., Prouillac, C., \& Lecoeur, S. (2012). Zearalenone exposure modulates the expression of $\mathrm{ABC}$ transporters and nuclear receptors in pregnant rats and fetal liver. Toxicology Letters, 211, 246-256.

Leblanc, J. C., Guerin, T., Noel, L., Calamassi-Tran, G., Volatier, J. L., \& Verger, P. (2005). Dietary exposure estimates of 18 elements from the 1st French Total diet study. Food Additives and Contaminants, 22, 624-641.

Lee, J., Kim, H., Jeon, J. J., Kim, H. S., Zeller, K. A., Carter, L. L., Leslie, J. F., \& Lee, Y. W. (2012). Population structure of and mycotoxin production by Fusarium graminearum from maize in South Korea. Applied and Environmental Microbiology, 78, 2161-2167.

Li, R. J., BT, P. M. H., Liu, Y. C., \& Dong, J. G. (2015). Natural occurrence of fumonisins $B 1$ and $B 2$ in maize from three main maize-producing provinces in China. Food Control, 5, 11-16.

Li, Y., Wang, Z., Beier, R. C., Shen, J., De, S. D., De Saeger, S., \& Zhang, S. (2011). T-2 toxin, a trichothecene mycotoxin: Review of toxicity, metabolism, and analytical methods. Journal of Agricultural and Food Chemistry, 59, 3441-3453.

Lippolis, V., Pascale, M., Maragos, C. M., \& Visconti, A. (2008). Improvement of detection sensitivity of $\mathrm{T}-2$ and $\mathrm{HT}-2$ toxins using different fluorescent labeling reagents by high-performance liquid chromatography. Talanta, 74, 1476-1483.

Madheswaran, R., Balachandran, C., \& Murali Manohar, B. (2004). Influence of dietary culture material containing aflatoxin and $\mathrm{T}$ (2) toxin on certain serum biochemical constituents in Japanese quail. Mycopathologia, 158, 337-341.

Maresca, M. (2013). From the gut to the brain: Journey and pathophysiological effects of the food-associated trichothecene mycotoxin deoxynivalenol. Toxins, 5, 784-820.

Marin, D. E., Taranu, I., Burlacu, R., Manda, G., Motiu, M., Neagoe, I., Dragomir, C., Stancu, M., \& Calin, L. (2011). Effects of zearalenone and its derivatives on porcine immune response. Toxicology in vitro : An International Journal Published in Association with BIBRA, 25, 1981-1988.

Marin, S., Ramos, A. J., Cano-Sancho, G., \& Sanchis, V. (2013). Mycotoxins: Occurrence, toxicology, and exposure assessment. Food and Chemical Toxicology : an international journal published for the British Industrial Biological Research Association., 60, 218-237.

McCormick, S. P. Stanley, A. M., Stover, N. A., \& Alexander, N. J. (2011). Trichothecenes: From simple to complex mycotoxins. Toxins., 3, 802-814.

Moretti, A., Logrieco, A. F., \& Susca, A. (2017). Mycotoxins: An underhand food problem. Methods in Molecular Biology., 1542, 3-12.
Nagashima, H., \& Nakagawa, H. (2014). Differences in the toxicities of Trichothecene Mycotoxins, Deoxynivalenol and Nivalenol, in cultured cells. Japan Agricultural Research Quarterly, 48, 5-12.

Ndossi, D. G., Frizzell, C., Tremoen, N. H., Faeste, C. K., Verhaegen, S., Dahl, E., Eriksen, G. S., Sorlie, M., Connolly, L., \& Ropstad, E. (2012). An in vitro investigation of endocrine disrupting effects of trichothecenes deoxynivalenol (DON), T-2 and HT-2 toxins. Toxicology Letters, 214, 268-278.

Nemcsok, J., \& Boross, L. (1982). Comparative studies on the sensitivity of different fish species to metal pollution. Acta biologica Academiae Scientiarum Hungaricae., 33, 23-27.

O'Donnell, K., Kistler, H. C., Tacke, B. K., \& Casper, H. H. (2000). Gene genealogies reveal global phylogeographic structure and reproductive isolation among lineages of Fusarium graminearum, the fungus causing wheat scab. Proceedings of the National Academy of Sciences of the United States of America, 97, 7905-7910.

O'Donnell, K., Ward, T. J., Geiser, D. M., Corby Kistler, H., \& Aoki, T. (2004). Genealogical concordance between the mating type locus and seven other nuclear genes supports formal recognition of nine phylogenetically distinct species within the Fusarium graminearum clade. Fungal Genetics and Biology, 41, 600-623.

Osborne, L. E, \& Stein, J. M. (2007). Epidemiology of Fusarium head blight on small-grain cereals. International Journal of Food Microbiology., 119, 103-108.

Ostry, V., Malir, F., Toman, J., \& Grosse, Y. (2017). Mycotoxins as human carcinogensthe IARC monographs classification. Mycotoxin Research, 33, 65-73.

Parikka, P., Hakala, K., \& Tiilikkala, K. (2012). Expected shifts in Fusarium species' composition on cereal grain in northern Europe due to climatic change. Food Additives \& Contaminants. Part A, Chemistry, Analysis, Control, Exposure \& Risk Assessment, 29, 1543-1555.

Peraica, M., Radic, B., Lucic, A., \& Pavlovic, M. (1999). Toxic effects of mycotoxins in humans. Bulletin of the World Health Organization, 77, 754-766.

Pinton, P., \& Oswald, I. P. (2014). Effect of deoxynivalenol and other Type B trichothecenes on the intestine: A review. Toxins, 6, 1615-1643.

Pistol, G. C., Gras, M. A., Marin, D. E., Israel-Roming, F., Stancu, M., \& Taranu, I. (2014). Natural feed contaminant zearalenone decreases the expressions of important pro-and anti-inflammatory mediators and mitogen-activated protein kinase/NF-kappaB signalling molecules in pigs. The British Journal of Nutrition, 111, 452-464.

Qiu, J. B., \& Shi, J. R. (2014). Genetic relationships, carbendazim sensitivity and mycotoxin production of the Fusarium graminearum populations from maize, wheat and rice in eastern China. Toxins, 6, 2291-2309.

Ricciardi, C., Castagna, R., Ferrante, I., Frascella, F., Marasso, S. L., Ricci, A., Canavese, G., Lore, A., Prelle, A., Gullino, M. L., \& Spadaro, D. (2013). Development of a microcantilever-based immunosensing method for mycotoxin detection. Biosensors \& Bioelectronics, 40, 233-239.

Rotter, B. A., Prelusky, D. B., \& Pestka, J. J. (1996). Toxicology of deoxynivalenol (vomitoxin). Journal of Toxicology and Environmental Health, 48, 1-34.

Rui Li, X. W., Zhou, T., Yang, D., Qi, W., \& Zhou, Y. (2014). Occurrence of four mycotoxins in cereal and oil products in Yangtze Delta region of China and their food safety risks. Food Control, 35, 7.

Schoevers, E. J., Santos, R. R., Colenbrander, B., Fink-Gremmels, J., \& Roelen, B. A. (2012). Transgenerational toxicity of Zearalenone in pigs. Reproductive Toxicology, 34, 110-119.

Scott, P. M. (2012). Recent research on fumonisins: A review. Food additives \& contaminants. Part A, Chemistry, Analysis, Control, Exposure \& Risk Assessment., $29,242-248$

Sehata, S., Kiyosawa, N., Makino, T., Atsumi, F., Ito, K., Yamoto, T., Teranishi, M., Baba, Y., Uetsuka, K., Nakayama, H., \& Doi, K. (2004). Morphological and microarray analysis of $\mathrm{T}-2$ toxin-induced rat fetal brain lesion. Food and Chemical Toxicology : an International Journal Published for the British Industrial Biological Research Association, 42, 1727-1736.

Selvaraj, J. N., Wang, Y., Zhou, L., Zhao, Y., Xing, F., Dai, X., \& Liu, Y. (2015). Recent mycotoxin survey data and advanced mycotoxin detection techniques reported from China: A review. Food Additives \& Contaminants. Part A, Chemistry, Analysis, Control, Exposure \& Risk Assessment., 32, 440-452.

Severino, L., Luongo, D., Bergamo, P., Lucisano, A., \& Rossi, M. (2006). Mycotoxins nivalenol and deoxynivalenol differentially modulate cytokine mRNA expression in Jurkat T cells. Cytokine, 36, 75-82.

Shifrin, V. I., \& Anderson, P. (1999). Trichothecene mycotoxins trigger a ribotoxic stress response that activates c-Jun N-terminal kinase and p38 mitogenactivated protein kinase and induces apoptosis. The Journal of Biological Chemistry, 274, 13985-13992. 
Shinozuka, J., Suzuki, M., Noguchi, N., Sugimoto, T., Uetsuka, K., Nakayama, H., \& Doi, K. (1998). T-2 toxin-induced apoptosis in hematopoietic tissues of mice Toxicologic Pathology, 26, 674-681.

Smyth, S. J., McDonald, J., \& Falck-Zepeda, J. (2014). Investment, regulation, and uncertainty: Managing new plant breeding techniques. GM Crops \& FoodBiotechnology in Agriculture and the Food Chain, 5, 44-57.

Soriano, J. M., Gonzalez, L., \& Catala, A. I. (2005). Mechanism of action of sphingolipids and their metabolites in the toxicity of fumonisin B1. Progress in Lipid Research, 44, 345-356.

Soriano, J. M. D. S. (2004). Occurrence of fumonisins in foods. Food Research International, 37, 6.

Starkey, D. E., Ward, T. J., Aoki, T., Gale, L. R., Kistler, H. C., Geiser, D. M., Suga, H., Toth, B., Varga, J., \& O'Donnell, K. (2007). Global molecular surveillance reveals novel Fusarium head blight species and trichothecene toxin diversity. Fungal Genetics and Biology, 44, 1191-1204.

Suga, H., Karugia, G. W., Ward, T., Gale, L. R., Tomimura, K., Nakajima, T., Miyasaka, A., Koizumi, S., Kageyama, K., \& Hyakumachi, M. (2008). Molecular characterization of the Fusarium graminearum species complex in Japan. Phytopathology, 98, 159-166.

Summerell, B. A., \& Leslie, J. F. (2011). Fifty years of Fusarium: How could nine species have ever been enough? Fungal Diversity, 50, 10.

Tatsuno, T., Inoue, T., \& Tanimura, A. (1979). Hygienic chemical studies on plastics (II). Residual acrylonitrile in ABS resin or AS resin and its migration into water (author's transl). Eisei Shikenjo Hokoku. Bulletin of National Institute of Hygienic Sciences, 97, 93-97.

Thrane, U., Adler, A., Clasen, P. E., Galvano, F., Langseth, W., Lew, H., Logrieco, A., Nielsen, K. F., \& Ritieni, A. (2004). Diversity in metabolite production by Fusarium langsethiae, Fusarium poae, and Fusarium sporotrichioides. International Journal of Food Microbiology, 95, 257-266.

Torres-Chavolla, E., \& Alocilja, E. C. (2009). Aptasensors for detection of microbial and viral pathogens. Biosensors \& Bioelectronics., 24, 3175-3182.

Turner, P. (2010). Deoxynivalenol and nivalenol occurrence and exposure assessment. World Mycotoxin Journal, 3, 7-16.

Ueno, Y., Nakajima, M., Sakai, K., Ishii, K., \& Sato, N. (1973). Comparative toxicology of trichothec mycotoxins: Inhibition of protein synthesis in animal cells. Journal of Biochemistry, 74, 285-296.

Van Egmond, H. P., Schothorst, R. C., \& Jonker, M. A. (2007). Regulations relating to mycotoxins in food: Perspectives in a global and European context. Analytical and Bioanalytical Chemistry, 389, 147-157.

Visconti, A., \& De Girolamo, A. (2005). Fitness for purpose--ochratoxin a analytical developments. Food Additives and Contaminants, 1(22 Suppl), 37-44.

Wan, L. Y., Turner, P. C., \& El-Nezami, H. (2013). Individual and combined cytotoxic effects of Fusarium toxins (deoxynivalenol, nivalenol, zearalenone and fumonisins B1) on swine jejunal epithelial cells. Food and Chemical Toxicology : an International Journal Published for the British Industrial Biological Research Association, 57, 276-283.

Wang, J. H., Li, H. P., Qu, B., Zhang, J. B., Huang, T., Chen, F. F., \& Liao, Y. C. (2008). Development of a generic PCR detection of 3-acetyldeoxy-nivalenol-, 15acetyldeoxynivalenol- and nivalenol-chemotypes of Fusarium graminearum clade. International Journal of Molecular Sciences, 9, 2495-2504.

Ward, T. J., Bielawski, J. P., Kistler, H. C., Sullivan, E., \& O'Donnell, K. (2002). Ancestral polymorphism and adaptive evolution in the trichothecene mycotoxin gene cluster of phytopathogenic Fusarium. Proceedings of the National Academy of Sciences of the United States of America, 99, 9278-9283.

Wei, T., Zhu, W., Pang, M., Liu, Y., \& Dong, J. (2013). Natural occurrence of fumonisins B1 and B2 in corn in four provinces of China. Food Additives \& Contaminants: Part B, 6, 5.

Weidner, M., Lenczyk, M., Schwerdt, G., Gekle, M., \& Humpf, H. U. (2013). Neurotoxic potential and cellular uptake of T-2 toxin in human astrocytes in primary culture. Chemical Research in Toxicology, 26, 347-355.

Xu, X., \& Nicholson, P. (2009). Community ecology of fungal pathogens causing wheat head blight. Annual Review of Phytopathology, 47, 83-103.

Xu, X. M., \& Berrie, A. M. (2005). Epidemiology of mycotoxigenic fungi associated with Fusarium ear blight and apple blue mould: A review. Food Additives and Contaminants, 22, 290-301.

Zeller, K. A., Summerell, B. A., Bullock, S., \& Leslie, J. F. (2003). Gibberella konza (Fusarium konzum) sp. nov. from prairie grasses, a new species in the Gibberella fujikuroi species complex. Mycologia, 95, 943-954.

Zhang, Z., Zhang, H., Lee, T. V. D., Chen, W. Q., Arens, P., Xu, J., Xu, J. S., Yang, L. G. , Yu, D. Z., Waalwijk, C., \& Feng, J. (2010). Geographic substructure of
Fusarium asiaticum isolates collected from barley in China. European Journal of Plant Pathology, 127, 10-18.

Zherdev, V. (2014). Immunochromatographic methods in food analysis. TrAC Trends in Analytical Chemistry, 55, 13-19.

Zhou, H. R., Lau, A. S., \& Pestka, J. J. (2003). Role of double-stranded RNAactivated protein kinase $R$ (PKR) in deoxynivalenol-induced ribotoxic stress response. Toxicological Sciences: An Official Journal of the Society of Toxicology, 74, 335-344.

Hujia, W., Li, T., Minjuan, W., Caixia, W., Rong, G. \& Haiou, Q. (2017). Mycotoxins contamination in 120 corn products on sale Shaanxi. Modern Preventive Medicine, 44,1593-1606.

Jiaojie, M., Bing, S., Xiaohui, L., Hongxia, Y. \& Fengqin, L. (2011). Study on the natural occurrence of multi-mycotoxin in cereal and cereal-based product samples collected from parts of China in 2010. Chinese Journal of Food Hygiene, 23, 481-488.

Kaihua, X., Wei, H., Mengjuan, W., Hua, W. \& Bocai, C. (2009). A survey on contamination of deoxynivalenol and zearalenol in maize and wheat from Anhui and Henan Province. Food Science, 30, 265-268.

Guohua, L., Gaolong, H., Zhihui, G., Weirong, W., Rongan, Z. \& Fenglin, H. (1993). Investigation on DON pollution of corn and flour in Hebei Province. Chinese Journal of Food Hygiene, 5, 40-41.

Yan, Y., Yuqin, Z. \& Ruiying, L. (1999). The contamination status of fumonisin in staple foods in Shandong Province and the ability of toxin producing toxins. Chinese Journal of Health Laboratory Technology, 9, 201-201.

Wuchang, S., Guihua, L., Hong, Y., Xiangyun, K. \& Xin, H. (2005). Investigation of fungal and mycotoxin contamination in food. Chinese Journal of Public Health, 12, 1532.

Bin, L., Maohui, X. \& Xiaomin, Y. (2005). Investigation on the contamination status of fumonisin and its toxin-producing fungi in the main grain of Hubei Province. Journal of Public Health and Preventive Medicine, 3, 60.

Xing, L., Hongwei, G., Jie, X., Tao, W. \& Ling, L. (1997). Studies on mycotoxins contamination of wheat in Shanghai. Shanghai Journal of Preventive Medicine, 9, 413-415.

Xueyun, L. Contamination of fusarium mycotoxin in grain. (1989). Chinese Journal of Food Hygiene, 1, 42-45.

Gang, L. (1994). The cotamination of deoxynivalenol in the cereals and products of Anhui Province. Chinese Journal of Preventive Medicine, 28, 27-30.

Chuanmin, C., Fan, B., Yun, L., Min, W., Xiaofang, Z., Yuping, W. \& Qingjun, G. (2014). Investigation on the contamination of mycotoxins in wheat feed in 2013. Cereal and Feed Industry, 6, 41-46.

Jie, W., Taiguo, L., Li, G., Baocheng, Z. \& Wanquan, C. (2009). Determination of 4 fusarium mycotoxins using enzyme-linked immunosorbent assay and its contamination analysis in wheat. Journal of Plant Protection, 36, 106-112.

Chuanhe Y., Xueyun, L., Rong, J. \& Chang, L. (1992). A survey of T-2 toxin in wheat by an indirect enzyme-linked immunosorbent assay. Acta Microbiologica Sinica, 32, 450-455.

Yifeng, C., Ping, Z., Guilan, W. \& Wei, W. (1995). A survey of T-2 toxin in wheat in Guizhou Province. Chinese Journal of Food Hygiene, 4, 43-44.

Yumei, H., Ze, Z. \& Zhenzhen, J. (1998). Investigation on the contamination of T-2 toxin in wheat stocks in Beijing. Chinese Journal of Food Hygiene, 6, 24-26.

Xiaomin, H., Fengqin, L., Wenjing, X., Hongyuan, Z., Jin, Z., Xi, Z., Jin, X. \& Chunhui. , H. (2017). Natural occurrence of important mycotoxins produced by fusarium in wheat flour from five provinces in China. China Swine Industry, $12,33-40$.

Chuang, Z., Chenghua, H., Huiming, S., Rongjia, L. \& Haibing, Z. (2014). Investigation of mycotoxin contamination of feed and raw materials in China in 2012. Animal Husbandry and Veterinary Medicine, 46, 81-84.

Bifang, C. (1997). The current status of feed mold and mycotoxins pollution in China. Chinese Journal of Pharmacology and Toxicology, 11, 91-92.

Huilan, J., Chenming, T., Yali, D. \& Xiaoming, Q. (2011). Investigation on the contamination status of combined feed mycotoxins in Guangxi Province. Feed Industry, 32, 59-62.

Marasas, W. F. O., Kellerman, T. S., Gelderblom, W. C., Thiel, P. G., Van der Lugt, J. J. , \& Coetzer, J. A. (1988). Leukoencephalomalacia in a horse induced by fumonisin B1 isolated from Fusarium moniliforme. Onderstepoort Journal of Veterinary Research, 55, 197-203.

Rui, Li, X.W., Ting., Z., Dongxu, Y., Qi, W., Yu, Z. (2014). Occurrence of four mycotoxins in cereal and oil products in Yangtze Delta region of China and their food safety risks. Food Control, 35, 7.

Renjie, L., Tiesong, W., Congcong, G., Minhao, P., Yinchao, L., Jingao, D. (2015) Effects of infestation by Helicoverpa armigera together with Fusarium 
verticillioides on the severity of maize ear rot and the contamination level of fumonisin in kernels. Plant Protection, 41, 68-72.

Adrián Jodra, Miguel Ángel, López, Alberto Escarpa. (2015). Disposable and reliable electrochemical magnetoimmunosensor for Fumonisins simplified determination in maize-based foodstuffs. Biosensors and Bioelectronics, 64, 633-638.

Liu, L., Chao, Y., Cao, W., Wang, Y., Luo, C., Pang, X., Fan, D. \& Wei, Q. (2014). A label-free amperometric immunosensor for detection of zearalenone based on trimetallic Au-core/AgPt-shell nanorattles and mesoporous carbon. Analytica chimica acta, 847, 29-36.

Siegmund, O. H., McPhate, J., Tremsin, A. S., Vallerga, J. V., Frisch, H. J., Wagner, R. G., ... \& Varner, G. (2013). Large Area flat panel Photon Counting Imaging Detectors for Astronomy and Night Time Sensing. In Advanced Maui Optical and Space Surveillance Technologies Conference.

Song, S., Liu, N., Zhao, Z., Njumbe Ediage, E., Wu, S., Sun, C., Saeger, S.D \& Wu, A. (2014). Multiplex lateral flow immunoassay for mycotoxin determination. Analytical chemistry, 86, 4995-5001.

Kun, W., Yuze, H., Xiaofei, H., Yao, W., Wenjun, L., Yafeng, P., Ruiguang, D. (2013). Time-resolved fluorescence immunoassay techniques for the detection of mycotoxins. Chinese Journal of Immunology, 2, 197-201.

\section{Publisher's Note}

Springer Nature remains neutral with regard to jurisdictional claims in published maps and institutional affiliations.

Ready to submit your research? Choose BMC and benefit from:

- fast, convenient online submission

- thorough peer review by experienced researchers in your field

- rapid publication on acceptance

- support for research data, including large and complex data types

- gold Open Access which fosters wider collaboration and increased citations

- maximum visibility for your research: over $100 \mathrm{M}$ website views per year

At BMC, research is always in progress.

Learn more biomedcentral.com/submissions 